\title{
Konsep Ekonomi Ibn Khaldun dan Al-Ghazali
}

\author{
Aninda Aprilia (90100118031) \\ anindaaprilia038@gmail.com
}

Ibnu Khaldun dalam proses pemikirannya mengalami percampuran yang unik, yaituantara dua tokoh yang saling bertolak belakang, Al-Ghazali dan Ibnu Rusyd. Al Ghazali dan Ibnu Rusyd bertentangan dalam bidang filsafat. Ibnu Rusyd adalah pengikut Aristoteles yang setia, sedangkan Al-Ghazali adalah penentang filsafat Aristoteles yang gigih. Ibnu Khaldun adalah pengikut AlGhazali dalam permusuhannya melawan logika Aristoteles, dan pengikut Ibnu Rusyd dalam usahanya mempengaruhi massa.dan dalam hubungan antara filsafat dan agama Ibnu Khaldun terinspirasi dari Ibnu Rusyd, bahkan pandangan Ibnu Khaldun dituding merupakan kelanjutan dari pemikiran Ibnu Rusyd. Tetapi dalam posisi lain Ibnu Khaldun berbeda pandangan dengan Ibnu Rusyd, Ibnu Rusyd mencela filsafat terutama mengenai metafisika. Dalam hal ini bisa dilihat bahwa Ibnu Khaldun berhasil menyatukan filsafat Al Ghazali dan Ibnu Rusyd. Dengan sintesis ini Ibnu Khaldun berhasil membangun corak pemikiran yang baru yaitu rasionalistik-sufistik. Dengan berpola pikir seperti itulah Ibnu Khaldun mengamati dan menganalisa gejala- gejala sosial besertasejarahnya, yang pada akhirnya tercipta suatu teori kemasyarakatan yang modern.(Nasrowi, 2017)

Pemikiran ekonomi al-Ghazali memiiki kekhasan tersendiri dibanding pemikir yang lain. Dalam grand konsep ekonominya, al-Ghazali memfokuskan perhatiannya pada perilaku individu yang dibahasnya menurut perspektif Al-Qur"an, Sunnah, fatwa-fatwa sahabat dan tabiein serta petuah para sufi terkemuka masa sebelumnya, seperti Junaid Al-Baghdadi, Dzun Al-Mishri, dan Harits bin Asad Al- Muhasibi.Berkaitan dengan kekhasan pemikiran ekonomi al-Ghazali, maka penulis begitu tertarik dan concern untuk mengkajinya lebih dalam. Harapan penulis, dengan dibahasnya pemikiran ekonomi para pemikir Islam, wacana ekonomi Islam di kalangan akademisi menjadi makin semarak, nuansa ekonomi Islam di Indonesia menjadi berkembang dan operasionalisasi lembaga keuangan syariah di Indonesia semakin maju dan komprehensif.(Rahmawati, 2012)

Menurut Imam al-Ghazali landasan, terjadinya mekanisme pasar adalah sifat kasih sayang. Wujud dasar ikatan mekanisme pasar tersebut adalah aqad yang diucapkan antara konsumen dan produsen. Paradigma ini lah yang menjadi landasan Imam al-Ghazali dalam membangun teori mengenai unsur-unsur yang membentuk mekanisme pasar. Nampak, corak unsur-unsur mekanisme pasar Imam al-Ghazali bersifat dogmatis karena bersumber dari agama dan rasional 
karena didalamnya mengandung pertimbangan akal. Unsur mekanisme pasar yang bercorak dogmatis-rasional disebutkan oleh Imam al-Ghazali sebagai rukun jual beli, yaitu dua orang yang melakukan transaksi, obyek transaksi dan aqad transaksi. Bagi Imam al-Ghazali keberadaan pasar merupakan sunnatullah atas taqdir manusia sebagai makhluk sosial, dimana ia tidak dapat hidup sendirian melainkan perlu berkumpul dengan orang lain. Sehingga manusia perlu saling tolong menolong dalam menyiapkan sebab- sebab makanan, pakaian dan mendidik anak-anak. Disamping itu Imam al- Ghazali juga menjelaskan jenis pasar yang dapat diwujudkan dalam kehidupan manusia yaitu pasar faktor produksi dan pasar barang.(Suprihatin, Suprihatin. Ibdalsyah, 2018)

Al-Gazali berada dalam era kehidupan ekonomi Islam era feodal militer atau perbudakan. Era ini ditandai dengan dominasi kehidupan agraris yang dikendalikan oleh pihak penguasa yang selalu mengawasi kegiatan para buruh. Dalam pada itu pihak penguasa berusaha mencari legitimasi atas tindakan mereka dengan cara-cara birokratik ataupun meminta bantuan kepada para pemuka agama untuk memberikan fatwa yang membenarkan tindakan tersebut, serta dengan gempuran kebudayaan dimana pemerintah membangun sarana-sarana pendidikan. Pada sisi lain, kondisi demikian membawa berbagai dampak positif bagi kemajuan keilmuan dan perekonomian. Pesatnya perkembangan keilmuan pada masa al-gazali yang ditopang oleh besarnya dukungan dari pemerintah, termasuk dukungan materi dalam jumlah yang sangat besar tak pelak lagi menunjukkan kondisi obyektif perekonomian umat Islam pada waktu itu. (sirajuddin n.d.)

Nasrowi, B. M. (2017). Konsep Pendidikan Islam Perspektif Kitab Muqaddimah Ibnu Khaldun. 8.

Rahmawati, L. (2012). Konsep Ekonomi Al-Ghazali. Maliyah, 02(01), 329-345.

Suprihatin, Suprihatin. Ibdalsyah, H. T. (2018). Analisis Pemikiran Imam Al-Ghazali Mengenai Mekanisme. Islamic Economy, 7308(1), 42-57.

sirajuddin. n.d. konsep ekonomi al ghazali 1-4. 